\title{
Standardizing the Nomenclature for Clonal Lineages of the Sudden Oak Death Pathogen, Phytophthora ramorum
}

\author{
Niklaus J. Grünwald, Erica M. Goss, Kelly Ivors, Matteo Garbelotto, Frank N. Martin, Simone Prospero, Everett Hansen, \\ Peter J. M. Bonants, Richard C. Hamelin, Gary Chastagner, Sabine Werres, David M. Rizzo, Gloria Abad, Paul Beales, \\ Guillaume J. Bilodeau, Cheryl L. Blomquist, Clive Brasier, Stephan C. Brière, Anne Chandelier, Jennifer M. Davidson, \\ Sandra Denman, Marianne Elliott, Susan J. Frankel, Ellen M. Goheen, Hans de Gruyter, Kurt Heungens, Delano James, \\ Alan Kanaskie, Michael G. McWilliams, Willem Man in 't Veld, Eduardo Moralejo, Nancy K. Osterbauer, \\ Mary E. Palm, Jennifer L. Parke, Ana Maria Perez Sierra, Simon F. Shamoun, Nina Shishkoff, \\ Paul W. Tooley, Anna Maria Vettraino, Joan Webber, and Timothy L. Widmer
}

First and second authors: Horticultural Crops Research Laboratory, USDA-ARS, Corvallis, OR 97330; third author: North Carolina State University, Mills River, NC 28759; fourth author: Department of Environmental Science, Policy, and Management, University of California, Berkeley, CA; fifth author: Crop Improvement and Protection Unit, USDA-ARS, Salinas, CA 93905; sixth author: WSL Swiss Federal Research Institute, 8903 Birmensdorf, Switzerland; seventh author: Botany and Plant Pathology, Oregon State University, Corvallis OR 97331; eighth author: Plant Research International, Wageningen UR, Wageningen, The Netherlands; ninth author: Natural Resources Canada, Department of Forest Sciences, The University of British Columbia, Vancouver, British Columbia, Canada; tenth author: Department of Plant Pathology, Washington State University, Research and Extension Center, Puyallup, WA 9837; eleventh author: Julius Kuehn Institut (JKI), Institute for Plant Protection in Horticulture and Forests, Braunschweig, Germany; twelfth author: University of California at Davis, Davis, CA 95616; thirteenth author and thirty-third authors: USDA APHIS, Beltsville, MD 20705; fourteenth author: Central Sciences Laboratory, York YO41 1LZ, N Yorkshire, England; fifteenth author: USDA-ARS, Salinas, CA, 93905; sixteenth author: California Department of Food and Agriculture, Sacramento, CA 95832; seventeenth, twenty-first, and fortieth authors: Forest Research, Alice Holt Lodge, Farnham, Surrey GU10 4LH, UK; eighteenth author: Canadian Food Inspection Agency, Ottawa, ON Canada; nineteenth author: Walloon Agricultural Research Centre (CRAW), B-5030 Gembloux, Belgium; twentieth author: University of Hawaii, Honolulu, HI 96822; twenty-second author: Washington State University, Puyallup, WA 98371; twenty-third author: USDA Forest Service, Pacific Southwest Research Station, Albany, CA 94710; twenty-fourth author: USDA Forest Service, Central Point, OR 97502; twenty-fifth and thirtieth authors: Plant Protection Service, Wageningen, $6700 \mathrm{HC}$, The Netherlands; twenty-sixth author: Institute for Agricultural and Fisheries Research (ILVO), 9820 Merelbeke, Belgium; twenty-seventh author: Canadian Food Inspection Agency, Sidney, BC V8L 1H3, Canada; twenty-eighth and twenty-ninth authors: Oregon Department of Forestry, Salem, OR 97310; thirty-first author: Instituto Mediterráneo de Estudios Avanzados, IMEDEA (CSIC-UIB), 07190, Esporles, Balearic Islands, Spain; thirty-second author: Oregon Department of Agriculture, Salem, OR 97310; thirty-fourth author: Dept. of Crop and Soil Science, Oregon State University, Corvallis, OR 97331; thirty-fifth author: Instituto Agroforestal Mediterráneo, Universidad Politécnica de Valencia (IAMUPV), 46022 Valencia, Spain; thirty-sixth author: Natural Resources Canada, Canadian Forest Service, Pacific Forestry Centre, Victoria, BC V8Z 1M5 Canada; thirty-seventh, thirty-eighth, and fourty-first authors: USDA-ARS FDWSRU, Fort Detrick, MD 21702; and thirtyninth author: Department of Plant Protection, University of Tuscia, Viterbo, 01100 Italy.

Accepted for publication 8 March 2009.

\begin{abstract}
Grünwald, N. J., Goss, E. M., Ivors, K., Garbelotto, M., Martin, F. N., Prospero, S., Hansen, E., Bonants, P. J. M., Hamelin, R. C., Chastagner, G., Werres, S., Rizzo, D. M., Abad, G., Beales, P., Bilodeau, G. J., Blomquist, C. L., Brasier, C., Brière, S. C., Chandelier, A., Davidson, J. M., Denman, S., Elliott, M., Frankel, S. J., Goheen, E. M., de Gruyter, H., Heungens, K., James, D., Kanaskie, A., McWilliams, M. G., Man in 't Veld, W., Moralejo, E., Osterbauer, N. K., Palm, M. E., Parke, J. L., Perez Sierra, A. M., Shamoun, S. F., Shishkoff, N., Tooley, P. W., Vettraino, A. M., Webber, J., and Widmer, T. L. 2009. Standardizing the nomenclature for clonal lineages of the sudden oak death pathogen, Phytophthora ramorum. Phytopathology 99:792-795.
\end{abstract}

ABSTRACT

Phytophthora ramorum, the causal agent of sudden oak death and ramorum blight, is known to exist as three distinct clonal lineages which can only be distinguished by performing molecular marker-based analyses.
However, in the recent literature there exists no consensus on naming of these lineages. Here we propose a system for naming clonal lineages of $P$. ramorum based on a consensus established by the $P$. ramorum research community. Clonal lineages are named with a two letter identifier for the continent on which they were first found (e.g., NA = North America; $\mathrm{EU}=$ Europe) followed by a number indicating order of appearance. Clonal lineages known to date are designated NA1 (mating type: A2; distribution: North America; environment: forest and nurseries), NA2 (A2; North America; nurseries), and EU1 (predominantly A1, rarely A2; Europe and North America; nurseries and gardens). It is expected that novel lineages or new variants within the existing three clonal lineages could in time emerge.

Additional keywords: exotic pathogen, forensics, molecular ecology, phylogeography, population genetics.
Corresponding author: N. J. Grünwald; E-mail address: Nik.Grunwald@ ars.usda.gov

* The $\boldsymbol{e}$-Xtra logo stands for "electronic extra" and indicates that the online version contains supplemental information providing the materials and methods used for producing Figure 1.

\section{doi:10.1094/PHYTO-99-7-0792}

This article is in the public domain and not copyrightable. It may be freely reprinted with customary crediting of the source. The American Phytopathological Society, 2009
Phytophthora ramorum Werres, De Cock \& Man in't Veld is the exotic pathogen responsible for causing sudden oak death of coast live oak and tanoak in native forests of the Western United States and in other trees in Europe and the United States. It also causes ramorum blight of trees and woody ornamentals such as rhododendron and camellia in forest, retail or wholesale nursery, and garden environments in North America and Europe $(4,13$, 
23,31,34,35,39). P. ramorum isolates examined to date comprise three distinct clonal lineages based on a range of molecular marker systems including amplified fragment length polymorphism (AFLP), microsatellites (SSR), mitochondrial and nuclear sequences, and single nucleotide polymorphisms (SNPs) $(1,26$, $27,29,32,33)$. However, the nomenclature used for these lineages is not consistent in the literature (Table 1). Thus, the objective of this letter is to provide a consensus nomenclature for P. ramorum clonal lineages based on current phenotypic and genotypic (molecular marker based) information.

All marker systems used to date have revealed the existence of these three clonal lineages. Figure 1 shows the three distinct evolutionary lineages of $P$. ramorum in dendrograms with significant bootstrap support based on either multilocus microsatellite (Fig. 1A) or mitochondrial sequence (Fig. 1B) data. Lineages are named with a two letter identifier for the continent on which they were first found (e.g., NA = North America; EU = Europe) followed by a number indicating order of identification. Lineage NA1, found in North America in nursery and forest environments, is mating type A2 and is the lineage first detected in California (Table 2). Lineage EU1 is now found both in Europe and North America, and is predominantly A1 mating type with rare findings of A2 isolates in Belgium (37) (Table 2). The third clonal lineage, NA2, currently is found only in North America in nurseries and is mating type A2 (Table 2). NA2 isolates were simultaneously found in California and Washington in nurseries (26) and have also been detected in Canada (11). Although both mating types are known to coexist in United States nurseries, the segregation of alleles that one would expect as a result of sexual reproduction between lineages has not yet been observed in any genotyped isolate $(22,26,31)$. While production of oospores in controlled crosses of A1 and A2 mating types is documented $(2,5)$, there are no published reports demonstrating viability of these oospores. There is evidence of historical recombination in at least two genes (19). However, it appears that the three P. ramorum clonal lineages have been reproductively isolated for at least 150,000 years if not longer based on nuclear sequence analyses (19).

Genes in the mitochondrial DNA (31) and certain microsatellite loci $(26,33)$ exhibit fixed lineage-specific alleles that easily distinguish the lineages at the molecular level. However, isolates within a given lineage have diverged considerably for other fastevolving microsatellites (Fig. 1A). Mitochondrial sequences generally have slower mutation rates than microsatellites (Fig. 1B; after [31]) and accordingly there is little variation in mitochondrial haplotypes within lineages. The three distinct clonal lineages and recent divergence within lineages are in agreement across all molecular marker based analyses published to date including AFLP (27), microsatellites (24,32,34), SNPs (1,31), mitochondrial sequences $(27,31,33)$, and nuclear sequences $(19,23,34)$. Regardless of the differences in the rate of divergence at these loci, isolates of these lineages can best be distinguished by performing either mitochondrial or microsatellite analyses.

Differences in sequences of mitochondrial loci have been found in isolates within lineages, e.g., NA1 isolates recovered from Oregon forests differ in one SNP and have been named NA1a and NA1b (31). Thus, we propose naming genetically distinct strains

TABLE 1. Placement of previously named genotypes of Phytophthora ramorum into the clonal lineages NA1, NA2, and EU1

\begin{tabular}{lccc}
\hline & \multicolumn{3}{c}{ Study } \\
\cline { 2 - 4 } Clonal lineage & Ivors et al. (26) & Prospero et al. (33) & Martin (31) \\
\hline NA1 & US1- US3; & PrOR1-PrOR32 & Haplotype IIa, IIb \\
NA2 & Clade 2 & & Haplotype III \\
EU1 & US4; & - & Haplotype I \\
& Clade 3 & PrOR33 & \\
\hline
\end{tabular}

within lineages based on SNPs by adding a letter to the lineage and strain designation, e.g., NA1a and NA1b in order of appearance.

We do not propose standardizing nomenclature for differences in genotypes for more variable markers systems such as microsatellites or AFLP given the rapid rate of divergence observed.

The three lineages show some differences in phenotype. Isolates belonging to lineages NA2 and EU1 exhibit faster mean radial growth in culture than those belonging to lineage NA1 $(3,6,26,38)$. Isolates of the NA1 lineage show more phenotypic variation in terms of growth morphology in petri dish culture or disease severity assays and instability of phenotype than those of the EU1 lineage $(6,38)$. Results on differences in pathogenicity among lineages are inconclusive at this point: there is some evidence that EU1 isolates are on average significantly more patho-

TABLE 2. Current nomenclature and characteristics of the known Phytophthora ramorum clonal lineages (adapted from Ivors et al. [26])

\begin{tabular}{lllcc}
\hline Clonal lineage & $\begin{array}{c}\text { Current } \\
\text { distribution }\end{array}$ & Environment & $\begin{array}{c}\text { Mating } \\
\text { type }\end{array}$ & $\begin{array}{c}\text { Colony } \\
\text { growth }^{\mathrm{a}}\end{array}$ \\
\hline NA1 & North America & $\begin{array}{c}\text { Forests, } \\
\text { nurseries }\end{array}$ & A2 & Slower \\
NA2 & $\begin{array}{l}\text { North America } \\
\text { EU1 }\end{array}$ & $\begin{array}{l}\text { Nurseries } \\
\text { Gardens, } \\
\text { North America } \\
\text { woodlands, } \\
\text { nurseries }\end{array}$ & $\begin{array}{c}\text { A2 } \\
\text { A1 }\end{array}$ & $\begin{array}{l}\text { Faster } \\
\text { Faster }\end{array}$ \\
\hline
\end{tabular}

a Based upon measurements of radial growth of representative isolates of each lineage grown on cornmeal or V8 juice agar $(3,6,26,38)$.

${ }^{\mathrm{b}}$ Lineage EU1 is predominantly of A1 mating type with rare findings of A2 isolates in Belgium (37).

${ }^{c}$ In the United States, the EU1 lineage is only found in nurseries, but is not very common relative to the NA1 lineage.
A

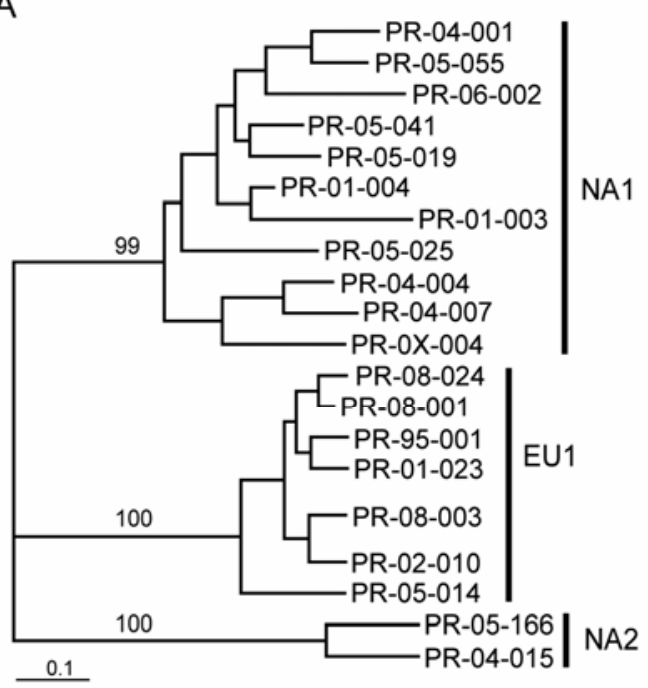

B

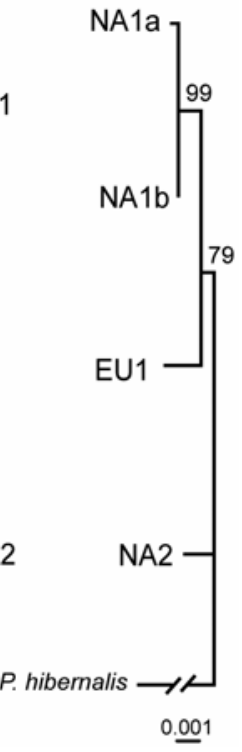

Fig. 1. Representative Phytophthora ramorum isolates from its known geographic range cluster into three distinct clonal lineages based on nuclear and mitochondrial molecular marker systems. Although some genetic diversity exists within a lineage, the lineages are clonal. The origins of isolates are listed in the online supplement. A, Neighbor-joining phylogram based on Nei's chord distance across six microsatellite loci. Bootstrap support values greater than $75 \%$ based on 1,000 bootstrap samples are shown (modified from Goss et al. [19] as described in supplement). B, Maximum likelihood tree for each $P$. ramorum mitochondrial haplotype for approximately $5 \mathrm{~kb}$ of DNA sequence from eight mitochondrial regions (modified from Martin [31] as described in supplement). The tree is rooted with $P$. hibernalis and bootstrap support values are based on 500 samples. 
genic to mature tree stems compared with NA1 isolates (6); however, other studies have revealed no differences in pathogenicity of isolates in different lineages to foliage or shoots $(7,25,36)$. Clearly, phenotype is not a suitable diagnostic test of clonal lineage; only molecular characterization can unambiguously place individuals within a lineage (23).

The clonal structure of $P$. ramorum is reminiscent of that of $P$. infestans and $P$. cinnamomi. Although $P$. infestans is known to exist as a sexually reproducing population in Europe and central Mexico $(12,20,21)$, its population structure in the United States is clonal $(15,16,18)$. Interestingly, the $P$. infestans US-1 clonal lineage known to exist in the United States prior to recent introductions has since been displaced by more fit clonal lineages such as US-8 $(16,17,28)$. Like $P$. ramorum, $P$. cinnamomi exists as distinct clonal lineages in Australia, South Africa, and elsewhere $(8,24,30)$. In a geographic area where both mating types coexist, Phytophthora populations can be sexually recombining as is the case for $P$. infestans in Europe $(9,10)$, or remain clonal as is the case for $P$. infestans in the United States and $P$. cinnamomi in Australia (14,22-24). It is expected that novel lineages or new variants of the existing three clonal lineages differing in the traits described herein could in time emerge.

\section{LITERATURE CITED}

1. Bilodeau, G. J., Levesque, C. A., de Cock, A., Briere, S. C., and Hamelin, R. C. 2007. Differentiation of European and North American genotypes of Phytophthora ramorum by real-time polymerase chain reaction primer extension. Can. J. Plant Pathol.-Rev. Can. De Phytopathol. 29:408-420.

2. Boutet, X., Laurent, F., and Chandelier, A. 2009. Influence of the medium-solidifying agent, the nutrient, and the genotype on the production of gametangia by Phytophthora ramorum in vitro. Mycol. Res. 113:110-116.

3. Brasier, C. 2003. Sudden oak death: Phytophthora ramorum exhibits transatlantic differences. Mycol. Res. 107:258-259.

4. Brasier, C., Denman, S., Brown, A., and Webber, J. 2004. Sudden Oak Death (Phytophthora ramorum) discovered on trees in Europe. Mycol. Res. 108:1108-1110.

5. Brasier, C., and Kirk, S. 2004. Production of gametangia by Phytophthora ramorum in vitro. Mycol. Res. 108:823-827.

6. Brasier, C., Kirk, S., and Rose, J. 2006. Differences in phenotypic stability and adaptive variation between the main European and American lineages of Phytophthora ramorum. Pages 166-173 in: Progress in Research on Phytophthora Diseases of Forest Trees. C. Brasier, T. Jung, and W. Oßwald, eds., Forest Research, Farnham.

7. Denman, S., Kirk, S. A., Brasier, C. M., and Webber, J. F. 2005. In vitro leaf inoculation studies as an indication of tree foliage susceptibility to Phytophthora ramorum in the UK. Plant Pathol. 54:512-521.

8. Dobrowolski, M. P., Tommerup, I. C., Shearer, B. L., and O'Brien, P. A. 2003. Three clonal lineages of Phytophthora cinnamomi in Australia revealed by microsatellites. Phytopathology 93:695-704.

9. Drenth, A., Goodwin, S. B., Fry, W. E., and Davidse, L. C. 1993. Genotypic diversity of Phytophthora infestans in the Netherlands revealed by DNA polymorphisms. Phytopathology 83:1087-1092.

10. Drenth, A., Janssen, E. M., and Govers, F. 1995. Formation and survival of oospores of Phytophthora infestans under natural conditions. Plant Pathol. 44:86-94.

11. Elliott, M., Sumampong, G., Varga, A., Shamoun, S. F., James, D., Masri, S., Brière, S. C., and Grünwald, N. J. 2009. PCR-RFLP markers identify three lineages of the North American and European populations of Phytophthora ramorum. For. Pathol. doi: 10.1111/j.1439-0329. 2008.00586.x

12. Flier, W. G., Grünwald, N. J., Kroon, L. P. N. M., Sturbaum, A. K., van den Bosch, G. B. M., Garay-Serrano, E., Fry, W. E., and Turkensteen, L. J. 2003. The population structure of Phytophthora infestans from the Toluca Valley in central Mexico suggests genetic differentiation between populations from cultivated potato and wild Solanum species. Phytopathology 93:382-390.

13. Frankel, S. J. 2008. Sudden oak death and Phytophthora ramorum in the USA: A management challenge. Australasian Plant Pathology 37: 19-25.

14. Fry, W. 2008. Phytophthora infestans: The plant (and R gene) destroyer. Mol. Plant Pathol. 9:385-402.

15. Fry, W. E., Goodwin, S. B., Dyer, A. T., Matuszak, J. M., Drenth, A., Tooley, P. W., Sujkowski, L. S., Koh, Y. J., Cohen, B. A., Spielman, L. J.,
Deahl, K. L., Inglis, D. A., and Sandlan, K. P. 1993. Historical and recent migrations of Phytophthora infestans: Chronology, pathways, and implications. Plant Dis. 77:653-661.

16. Goodwin, S. B., Cohen, B. A., Deahl, K. L., and Fry, W. E. 1994. Migration from northern Mexico as the probable cause of recent genetic changes in populations of Phytophthora infestans in the United States and Canada. Phytopathology 84:553-558.

17. Goodwin, S. B., Cohen, B. A., and Fry, W. E. 1994. Panglobal distribution of a single clonal lineage of the Irish potato famine fungus. Proc. Natl. Acad. Sci. 91:11591-11595.

18. Goodwin, S. B., and Drenth, A. 1997. Origin of the A2 mating type of Phytophthora infestans outside Mexico. Phytopathology 87:992-999.

19. Goss, E. M., Carbone, I., and Grünwald, N. J. 2009. Ancient isolation and independent evolution of the three clonal lineages of the exotic sudden oak death pathogen Phytophthora ramorum. Mol. Ecol. 18:11611174.

20. Grünwald, N. J., and Flier, W. G. 2005. The biology of Phytophthora infestans at its center of origin. Annu. Rev. Phytopathol. 43:171-190.

21. Grünwald, N. J., Flier, W. G., Sturbaum, A. K., Garay-Serrano, E., van den Bosch, T. B. M., Smart, C. D., Matuszak, J. M., Lozoya-Saldaña, H., Turkensteen, L. J., and Fry, W. E. 2001. Population structure of Phytophthora infestans in the Toluca Valley region of Central Mexico. Phytopathology 91:882-890.

22. Grünwald, N. J., Goss, E. M., Larsen, M. M., Press, C. M., McDonald, V. T. C. B., and Thomas, S. L. 2008. First report of the European lineage of Phytophthora ramorum on Viburnum and Osmanthus spp. in a California nursery. Plant Dis. 92:314-314.

23. Grünwald, N. J., Goss, E. M., and Press, C. M. 2008. Phytophthora ramorum: A pathogen with a remarkably wide host-range causing sudden oak death on oaks and ramorum blight on woody ornamentals. Mol. Plant Pathol. 9:729-740.

24. Hardham, A. R. 2005. Phytophthora cinnamomi. Mol. Plant Pathol. 6:589-604.

25. Huberli, D., Harnik, T. Y., Meshriy, M., Miles, L., and Garbelotto, M. 2006. Phenotypic variation among Phytophthora ramorum isolates from California and Oregon. Pages 131-134 in: Proceedings of the Sudden Oak Death Second Science Symposium: The State of Our Knowledge. Gen. Tech. Rep. PSW-GTR-196, S. J. Frankel, P. J. Shea, and M. I. Haverty, eds. U.S. Dep. Agric., For. Serv., Pacific Southwest Research Station, Albany, CA.

26. Ivors, K., Garbelotto, M., Vries, I. D. E., Ruyter-Spira, C., Hekkert, B. T., Rosenzweig, N., and Bonants, P. 2006. Microsatellite markers identify three lineages of Phytophthora ramorum in US nurseries, yet single lineages in US forest and European nursery populations. Mol. Ecol. 15:1493-1505.

27. Ivors, K. L., Hayden, K. J., Bonants, P. J. M., Rizzo, D. M., and Garbelotto, M. 2004. AFLP and phylogenetic analyses of North American and European populations of Phytophthora ramorum. Mycol. Res. 108:378-392.

28. Kato, M., Mizubuti, E. S. G., Goodwin, S. B., and Fry, W. E. 1997. Sensitivity to protectant fungicides and pathogenic fitness of clonal lineages of Phytophthora infestans in the United States. Phytopathology 87:973-978.

29. Kroon, L. P. N. M., Verstappen, E. C. P., Kox, L. F. F., Flier, W. G., and Bonants, P. J. M. 2004. A rapid diagnostic test to distinguish between American and European Populations of Phytophthora ramorum. Phytopathology 94:613-620.

30. Linde, C., Drenth, A., and Wingfield, M. J. 1999. Gene and genotypic diversity of Phytophthora cinnamomi in South Africa and Australia revealed by DNA polymorphisms. Eur. J. Plant Pathol. 105:667680 .

31. Martin, F. N. 2008. Mitochondrial haplotype determination in the oomycete plant pathogen Phytophthora ramorum. Curr. Genet. 54:23-34.

32. Mascheretti, S., Croucher, P. J. P., Vettraino, A., Prospero, S., and Garbelotto, M. 2008. Reconstruction of the Sudden Oak Death epidemic in California through microsatellite analysis of the pathogen Phytophthora ramorum. Mol. Ecol. 17:2755-2768.

33. Prospero, S., Hansen, E. M., Grünwald, N. J., and Winton, L. M. 2007. Population dynamics of the sudden oak death pathogen Phytophthora ramorum in Oregon from 2001 to 2004. Mol. Ecol. 16:2958-2973.

34. Rizzo, D. M., and Garbelotto, M. 2003. Sudden oak death: Endangering California and Oregon forest ecosystems. Front. Ecol. Environ. 1:197204.

35. Rizzo, D. M., Garbelotto, M., and Hansen, E. M. 2005. Phytophthora ramorum: Integrative research and management of an emerging pathogen in California and Oregon forests. Annu. Rev. Phytopathol. 43:309-335.

36. Tooley, P. W., Kyde, K. L., and Englander, L. 2004. Susceptibility of selected Ericaceous ornamental host species to Phytophthora ramorum. Plant Dis. 88:993-999. 
37. Werres, S., and De Merlier, D. 2003. First detection of Phytophthora ramorum mating type A2 in Europe. Plant Dis. 87:1266-1266.

38. Werres, S., and Kaminsky, K. 2005. Characterization of European and North American Phytophthora ramorum isolates due to their morphology and mating behaviour in vitro with heterothallic Phytophthora species.
Mycol. Res. 109:860-871.

39. Werres, S., Marwitz, R., Veld, W., De Cock, A., Bonants, P. J. M., De Weerdt, M., Themann, K., Ilieva, E., and Baayen, R. P. 2001. Phytophthora ramorum sp. nov., a new pathogen on Rhododendron and Viburnum. Mycol. Res. 105:1155-1165. 